Jurnal Ilmu - Ilmu Peternakan 26 (1): 1 - 6

ISSN: 0852-3681

E-ISSN: 2443-0765

CFakultas Peternakan UB, http://jiip.ub.ac.id/

\title{
Efisiensi penggunaan protein pada puyuh periode produksi yang diberi ransum mengandung tepung daun Kayambang (Salvinia molesta)
}

\author{
Hesty Rahmawati, Sri Kismiati, Warsono Sarengat \\ Fakultas Peternakan dan Pertanian Universitas Diponegoro \\ Kompl. drh. R. Soejono Koesoemowardojo-Tembalang, Semarang Kode Pos 50275
}

Hesty966@gmail.com

\begin{abstract}
The aim of the experiment was to determine the utilization of Kayambang (salvinia molesta)leaves meal on protein consumption, protein efficiency ratio, nitrogen retention, and digestibility protein. Experiment used 200 japanese female quails aged 9 weeks with average body weight $114.86 \pm 2.69 \mathrm{~g}$ (CV 2.34\%). The experiment was conducted in battery cages. The study used a completely randomized design with 4 treatments and 5 replications. The treatment diets were T0 (control), T1 (2.5\% Salvinia molesta leaves meal), T2 (5\% Salvinia molesta leaves meal) and T3 (7.5\% Salvinia molesta leaves meal). The dose of a liquid additive was $5 \mathrm{ml} /$ quail. Observation of crude protein digestibility and the energy was carried for 3 days and protein measurements were analysed using Kjeldahl method.The results showed that administration of salvinia molesta leaf meal up to $7.5 \%$ level in the diet decreased the quality of the rationso that the protein utilization was also decreased as indicated by the decline of protein consumption, protein efficiency ratio, nitrogen retention, and digestibility protein.
\end{abstract}

Keywords: quail, Kayambang (Salvinia molesta), protein efficiency

\section{PENDAHULUAN}

Puyuh merupakan unggas yang tujuan utama diternakkan sebagai petelur. Berdasarkan data dari Dirjen Peternakan dan Kesehatan Hewan (2015), populasi puyuh di Indonesia pada tahun 2015 mencapai 12.903.759 ekor. Faktor utama keberhasilan pemeliharaan puyuh berasal dari pakan yang sebagian besar tersusundari bahan pakan konvensional, ketersediaannya semakin langka, dan bersaing dengan unggas lain. Semakin tinggi kadar protein maka harga pakan semakin mahal, sehingga perlu mencari bahan pakan alternatif untuk memenuhi kebutuhan protein pembentukan telur puyuh.
Protein ransum unggas secara umum dipenuhi dari protein hewani seperti tepung ikan dan protein nabati seperti bungkil kedelai yang harganya cukup mahal dibandingkan bahan pakan lainnya. Alternatif bahan pakan lokal yang mempunyai kandungan protein tinggi, mudah diperoleh dengan harga murah dan tersedia cukup melimpah adalah Kayambang (Salvinia molesta).

Kayambang merupakan tanaman air yang tersedia cukup melimpah dan termasuk dalam limbah pertanian yang belum dimanfaatkan oleh masyarakat. Kandungan nutrisi pada Kayambang terdiri dari lemak kasar (LK) 2,1\%, protein kasar (PK) 15,9\%, dan serat kasar 
(SK) 16,8\%.Kandungan vitaminC pada Salvinia molesta sebesar $3,20 \mathrm{mg} / 30 \mathrm{~g}$ (Kurniawan dkk, 2010). Meliandasari dkk., (2015) menyatakan bahwa kandungan mineral dan pigmen xanthophyll dan $\beta$-karoten pada Kayambang diharapkan dapat meningkatkan efisiensi penggunaan ransum. Oleh karena itu, penelitian ini bertujuan untuk mengetahui efisiensi penggunaan protein pada puyuh periode produksi dengan menggunakan tepung daun Kayambang pada level berbeda dalam ransum.

\section{MATERI DAN METODE}

Penelitian ini dilaksanakan pada bulan Oktober 2015 - Januari 2016 di Laboratorium Unggas, Fakultas Peternakan dan Pertanian, Universitas Diponegoro. Materi penelitian sebanyak 200 ekor puyuh betina umur 6 hari dengan bobot 114,86 $\pm 2,69$ gram (CV $2,34 \%)$. Kandang yang digunakan adalah kandang bertingkat sebanyak 20 unit. Setiap unit kandang berukuran $90 \mathrm{~cm} \mathrm{x}$ $25 \mathrm{~cm} \times 20 \mathrm{~cm}$ yang dibagi secara acak berdasarkan Rancangan Acak Lengkap (RAL) dengan 4 perlakuan dan 5 ulangan. Setiap ulangan berisi 10 ekor puyuhyang sudah diseleksi pada umur 3 minggu. Perlakuan yang dicobakan adalah sebagai berikut :

T0: Ransum basal (kontrol)

T1: Ransum dengan 2,5\% tepung daun Salvinia molesta

T2: Ransum dengan 5\% tepung daun Salvinia molesta

T3: Ransum dengan $7,5 \%$ tepung daun Salvinia molesta

Pembuatan tepung daun Kayambang dilakukan dengan cara memisahkan daun dan akar Kayambang. Daun Kayambang dijemur hingga kering selama 2 hari, kemudian digiling menjadi tepung daun Kayambang.

Puyuh petelur dipelihara selama 12 minggu dengan pemeliharaan yang sama. Puyuh diberi campuran beberapa bahan pakan seperti yang tersaji pada Tabel 1. Sedangkan komposisi dan kandungan nutrisi ransum perlakuan disajikan pada Tabel 2.

Tabel 1. Kandungan nutrisi bahan pakan

\begin{tabular}{lllllll}
\hline Bahan pakan & EM1 & PK3 & LK2 & SK2 & Ca & P \\
\hline Jagung kuning & Kkal/kg & $----------------------\%$ & ------------------- \\
Bekatul & $3.197,68$ & 7,36 & 0,75 & 0,64 & 0,372 & 0,232 \\
Bungkil kedelai & $2.404,86$ & 7,80 & 3,68 & 6,36 & 0,372 & 1,272 \\
PMM & $3.295,30$ & 53,35 & 1,71 & 4,7 & 0,325 & 0,295 \\
MBM & $2.780,00$ & 73,37 & 11,45 & 11,6 & 6,455 & 3,266 \\
Salvinia molesta & 2737,82 & 51,63 & 10,01 & 5,5 & 10,305 & 5,104 \\
MCP & 2433,67 & 13,45 & 0,62 & 43,99 & 0,632 & 0,252 \\
CaCO3 & - & - & - & - & 16,004 & 21,004 \\
Premix & - & - & - & - & 38,004 & - \\
\hline
\end{tabular}

Sumber :

a. Hasil analisis proksimat di Laboratorium Ilmu Nutrisi dan Pakan Fakultas Peternakan dan Pertanian, Universitas Diponegoro. Perhitungan energi berdasarkan rumus Balton EM $(\mathrm{kkal} / \mathrm{kg})=40,81[0,87(\mathrm{PK}+2,25 \mathrm{x} \mathrm{LK}+\mathrm{BETN})$ $+\mathrm{k}]$

b. Hasil analisis proksimat di Laboratorium Ekologi dan Produksi Tanaman Fakultas Peternakan dan Pertanian, Universitas Diponegoro 
Tabel 2. Komposisi dan kandungan nutrisi ransum perlakuan

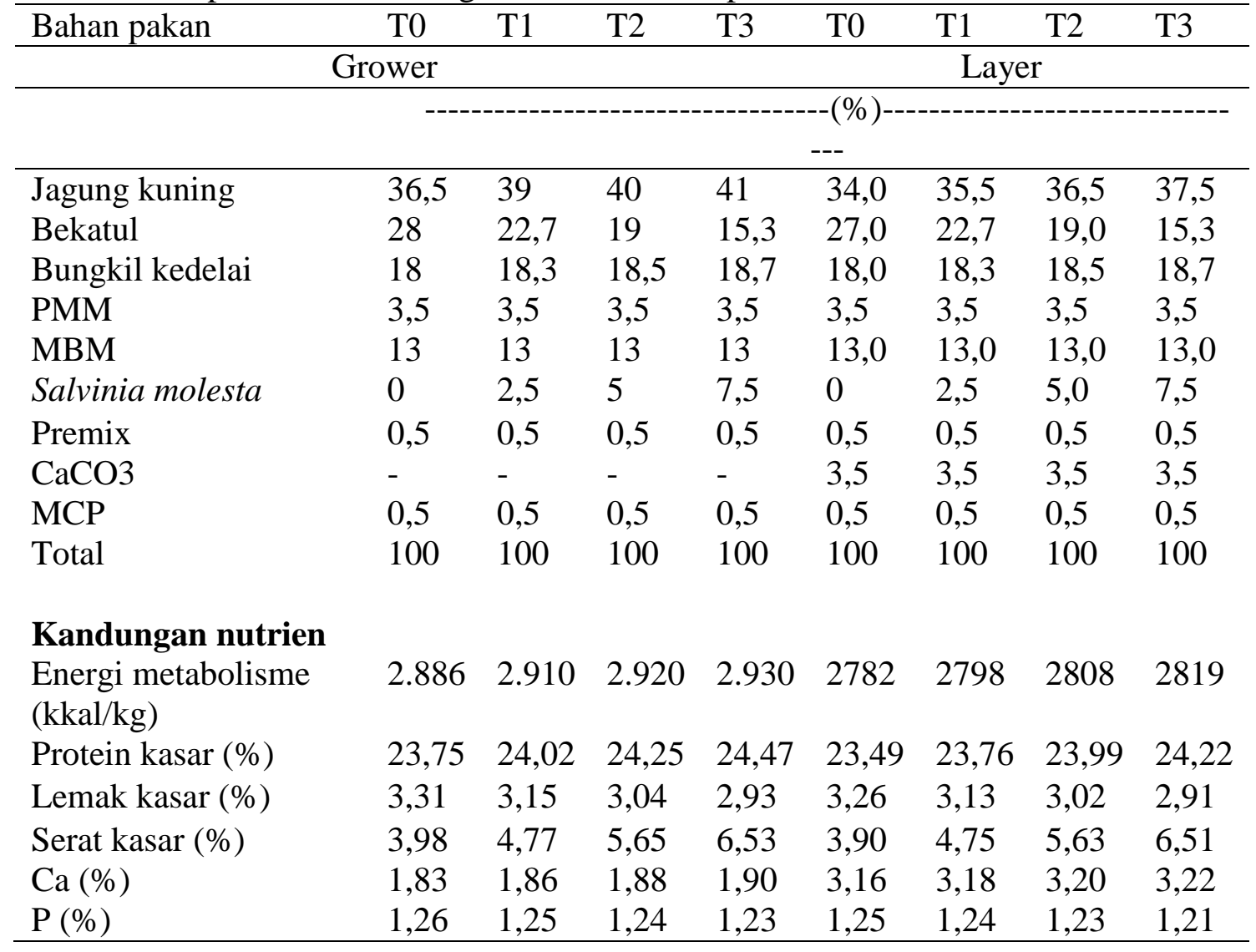

Pengamatan dilakukan mulai puyuh berumur 6-12 minggu. Selama tahap perlakuan dilakukan pencatatan pertambahan bobot badan dan konsumsi ransum untuk mendapat data perhitungan konsumsi protein. Rasio efisiensi protein dihitung dengan cara membandingkan massa telur dengan konsumsi protein dan retensi nitrogen diukur dengan cara menampung ekskreta puyuh dengan metode pewarnaan menggunakan kromat $\left(\mathrm{Cr}_{2} \mathrm{O}_{3}\right)$ selama 3 hari pada akhir penelitian.

a. Konsumsi protein (g) adalah jumlah protein yang dikonsumsi oleh ayam dan dihitung dengan rumus menurut Tillman, dkk., (1998) sebagai berikut:

Konsumsi protein $(\mathrm{g})=$

konsumsi pakan (g) x kadar PK ransum (\%)

b. Rasio efisiensi protein (REP)adalah perbandingan antara massa telur dengan konsumsi protein.
$\mathrm{REP}=\frac{\text { Massa telur }(\mathrm{g})}{\text { Konsumsi protein }(\mathrm{g})}$

c. Retensi nitrogen dihitung menggunakan rumus:

Retensi nitrogen $=\mathrm{N}$ intake $-(\mathrm{N}$ ekskreta $\mathrm{x} N$ endogenous)

Keterangan :

$\mathrm{N}=$ nitrogen

Data yang diperoleh dianalisis dengan ANOVA (uji F pada taraf uji 5\%). Apabila pada hasil analisis ragam terdapat pengaruh perlakuan dilanjutkan Uji Jarak Berganda Duncan untuk mengetahui letak perbedaannya.

\section{HASIL DAN PEMBAHASAN}

Hasil penelitian yang meliputi konsumsi protein, rasio efisiensi protein, retensi nitrogen, dan kecernaan protein disajikan pada Tabel 3. 
Tabel 3. Hasil penelitian pengaruh pemberian tepung daun Kayambang (Salvinia molesta) terhadap efisiensi penggunaan protein

\begin{tabular}{lccccc}
\hline \multirow{2}{*}{ Ulangan } & \multicolumn{4}{c}{ Perlakuan } & \multirow{2}{*}{ Rata-rata } \\
\cline { 2 - 4 } & T0 & T1 & T2 & T3 $n n$ & 4,38 \\
Konsumsi protein & 4,34 & 4,32 & 4,41 & 4,43 & 0,55 \\
REP & 0,58 & 0,58 & 0,52 & 0,51 & 0,45 \\
Retensi nitrogen & 0,45 & 0,42 & 0,47 & 0,46 & \\
\hline
\end{tabular}

\section{Pengaruh perlakuan terhadap} konsumsi protein

Hasil analisis ragam

menunjukkan bahwa pemberian tepung daun Kayambang tidak berpengaruh $(\mathrm{P}>0,05)$ terhadap rata-rata konsumsi protein. Rendahnya konsumsi protein disebabkan oleh bobot badan puyuh periode produksi yang kurang dari standar (143,1-151,1 gram). Amrullah (2003) menyatakan bahwa bobot badan terendah untuk mencapai dewasa tubuh minimal 150 gram sehingga umur dewasa kelamin tergantung dari pencapaian minimal dewasa tubuh. Listiyowati dan Roospitasari (2000) menyatakan bahwa konsumsi protein burung puyuh umur 6 minggu ke atas sebesar 20 gram/hari/ekor.

Tidak adanya pengaruh pada konsumsi protein karena dipengaruhi oleh konsumsi ransum yang juga tidak berbeda nyata. Anggorodi (1995) menyatakan bahwa konsumsi protein dipengaruhi oleh konsumsi pakan dan kandungan energi pakan. Kandungan energi dan protein yang sama dalam ransum akan menghasilkan konsumsi protein yang sama begitu pula sebaliknya. Hal ini sesuai dengan pendapat Wahju (1997) yang menyatakan bahwa konsumsi ransum dalam jumlah besar akan diikuti oleh konsumsi protein yang besar pula.

\section{Pengaruh perlakuan terhadap rasio efisiensi protein}

Hasil rasio efisiensi protein (REP) penelitian ini berkisar antara 0,51-0,58 atau lebih rendah dibandingkan dengan penelitian Suprijatna,dkk., (2009) yang melaporkan hasil imbangan REP adalah 0,64-0,96 menggunakan puyuh berumur 7-14 minggu. Situmorang, dkk,(2013) menjelaskan bahwa nilai REP dapat dipengaruhi oleh umur ternak dan kadar protein pakan. Semakin tinggi nilai REP maka ternak semakin efisien dalam memanfaatkan protein dalam ransum.

Iqbal, dkk., (2012) menyebutkan bahwa PBB sangat berpengaruh terhadap konsumsi protein karena PBB berasal dari protein yang menghasilkan sintesis protein. Pemberian tepung daun Kayambang sampai level 7,5\% dengan protein $24 \%$ dan energi metabolis 2800 $\mathrm{kkal} / \mathrm{kg}$ tidak meningkatkan nilai REP pada puyuh periode produksi. Semakin tinggi kandungan protein dalam ransum maka semakin kecil imbangan protein yang dapat mengakibatkan rendahnya nilai REP sehingga berpengaruh nyata pada nilai REP yang dihasilkan. Wahju (1997) menyatakan bahwa nilai REP berfungsi untuk menguji keefektifan dari protein ransum dimana jika nilai REP rendah maka efisiensi penggunaan protein pada ternak juga rendah.

\section{Pengaruh perlakuan terhadap retensi nitrogen}

Hasil penelitian menunjukkan bahwa penggunaan tepung daun Kayambang sampai level 7,5\% juga tidak berpengaruh nyata terhadap retensi nitrogen pada puyuh periode produksi. Hal ini disebabkan pada konsumsi protein dari berbagai perlakuan memiliki hasil 
yang tidak berpengaruh nyata, sedangkan tingkat energi tiap perlakuan sama. Faktor-faktor yang mempengaruhi retensi nirogen yaitu konsumsi protein, kualitas protein, dan energi metabolis (Wahju, 1997 dan Lopez and Leeson, 2005). Mangisah,dkk., (2008) menambahkan bahwa retensi nitrogen juga dapat dipengaruhi oleh serat kasar karena serat kasar dapat menyerap air dalam usus dan mengikat nutrisi didalam pakan termasuk protein sebagai sumber nitrogen sehingga susah dicerna.

Hasil penelitian ini lebih rendah dibandingkan dengan hasil penelitian Mahfudz,dkk., (2010) yang memperoleh nilai retensi nitrogen sebesar 0,7 dengan tingkat energi $2800 \mathrm{kkal} / \mathrm{kg}$ dan protein 24\%. Wahju (2004) menyatakan bahwa nilai retensi nitrogen yang tertinggal didalam tubuh lebih banyak sehingga nitrogen yang terbuang bersama dengan ekskreta semakin sedikit. Nilai retensi nitrogen yang tinggi dipengaruhi oleh meningkatnya level protein dalam ransum. Menurut Mc Donalder et al., (1977), nilai retensi nitrogen tergantung pada levelpemberian protein dalam pakan karena kandungan nitrogen yang diretensi sejalan dengan kandungan protein pakan.

\section{KESIMPULAN}

Penggunaan tepung daun Kayambang (Salvinia molesta) sebagai bahan pakan alternatif sampai level 7,5\% tidak menaikkan maupun menurunkan nilai konsumsi protein, rasio efisiensi protein (REP), retensi nitrogen, dan kecernaan protein pada puyuh periode produksi.

\section{DAFTAR PUSTAKA}

Anggorodi, R. 1995. Nutrisi aneka ternak unggas. PT. Gramedia Pustaka Utama, Jakarta.

Amrullah, I. K. 2003. Nutrisi ayambroiler. Lembaga Satu Gunungbudi, Bogor.
Dirjen Peternakan dan Kesehatan Hewan. 2015. Statistik peternakan dan kesehatan hewan. Dirjen Peternakan dan Kesehatan Hewan. Jakarta.

Iqbal, F., U. Atmomarsono, dan R. Muryani. 2012. Pengaruh berbagai frekuensi pemberian pakan dan pembatasan pakan terhadap efisiensi penggunaan protein ayam broiler. J. anim. Agric. 1 (1) : 53-64.

Lopez, G. and S. Leeson. 2005. Utilization of metabolizable energy by young broilers and birds of intermediate growth rate. Poultry Sci. 84 1069-1076.

Listiyowati, E. dan K. Roospitasari. 2000. Burung puyuh tata laksana budidaya secara komersil. Penebar Swadaya. Jakarta.

Kurniawan M, Izzati M, Nurchayati Y. 2010. Kandungan klorofil, karotenoid, dan vitamin $\mathrm{C}$ pada beberapa spesies tumbuhan akuatik. Buletin Anatomi dan Fisiologi. 18 (1): 28-40

Mahfudz, L. D., T. A. Sarjana dan W. Sarengat. 2010. Efisiensi penggunaan protein ransum yang mengandung limbah destilasi minuman beralkohol (LDMB) oleh burung puyuh (Coturnixcoturnix japonica) jantan. Seminar Nasional Teknologi Peternakan dan Veteriner.

Mangisah, I., N. Suthama, V. D. Yunianto dan D. Hastuti. 2008. Pengaruh berbagai level serat kasar dalam ransum terhadap retensi nitrogen dan massa protein daging. Bul. Peternakan 32 (2) : 78-84.

Mc Donald, P. R. A., Edwards and J. F. H. Greenhalgh. 1977. Animal nutrition. Fourth edition. Longman. Hongkong 
Meliandasari, D., Bambang Dwiloka dan Edjeng Suprijatna. 2015. Optimalisasi daun Kayambang (Salvinia molesta) untuk penurunan kolestrol daging dan peningkatan kualitas asam lemak esensial. Fakultas Peternakan dan Pertanian, Universitas Diponegoro, Semarang. Jurnal Aplikasi Teknologi Pangan 4 (1). Hal. 22-27.

Situmorang, N. A., L. D. Mahfudz dan U. Atmomarsono. 2013. Pengaruh pemberian tepung rumput laut (glacilaria verrucosa) dalam ransum terhadap efisiensi penggunaan protein ayam broiler. J. anim. Agric. 2 (2) : 49-56.

Suprijatna. E, Sunarti. D. dan U. Ni'mah. 2009. efisiensi penggunaan protein untuk produksi telur pada puyuh akibat pemberian ransum protein rendah yang disuplementasi lisin sintesis. Semnas Kebangkitan Peternakan. Semarang.

Tillman, A. D., H. Hartadi., S. Reksohadiprodjo., $\quad$ S. Prawirokusuma dan S. Lebdosoekoj. 1998. Ilmu makanan ternak dasar. Cetakan Keenam. Gadjah Mada University Press, Yogyakarta.

Wahju, J. 1997. Ilmu nutrisi unggas. Gadjah Mada University Press. Yogyakarta.

Wahju, J. 2004. Ilmu nutrisi unggas. Cetakan V, Gadjah Mada University Press. Yogyakarta. 